\title{
DOE FY 2010 Budget Request and Recovery Act Funding for Energy Research, Development, Demonstration, and Deployment: Analysis and Recommendations
}

\section{Citation}

Anadon, Laura Diaz, Kelly Sims Gallagher, and Matthew Bunn. 2009. DOE FY 2010 Budget Request and Recovery Act Funding for Energy Research, Development, Demonstration, and Deployment: Analysis and Recommendations. Cambridge: Report for Energy Technology Innovation Policy research group, Belfer Center for Science and International Affairs, Harvard Kennedy School.

\section{Published Version}

$10.2172 / 960197$

\section{Permanent link}

http://nrs.harvard.edu/urn-3:HUL.InstRepos:29914117

\section{Terms of Use}

This article was downloaded from Harvard University's DASH repository, and is made available under the terms and conditions applicable to Other Posted Material, as set forth at http:// nrs.harvard.edu/urn-3:HUL.InstRepos:dash.current.terms-of-use\#LAA

\section{Share Your Story}

The Harvard community has made this article openly available.

Please share how this access benefits you. Submit a story.

\section{Accessibility}




\section{DOE FY 2010 BUDGET REQUEST AND RECOVERY ACT FUNDING FOR ENERGY RESEARCH, DEVELOPMENT, DEMONSTRATION,AND DEPLOYMENT:}

\section{ANALYSIS AND RECOMMENDATIONS}

LAURA DIAZ ANADON, KELLY SIMS GALLAGHER, AND MATTHEW BUNN June 2009

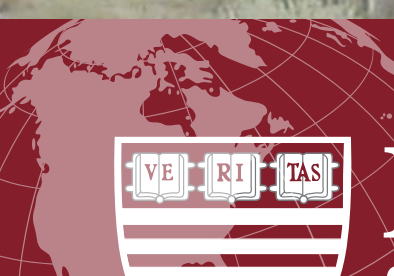

Belfer Center for Science and International Affairs John F. Kennedy School of Government Haryard University 


\section{ACKNOWLEDGMENTS}

The authors are grateful to the Climate Change Initiative of the Doris Duke Charitable Foundation for supporting the work of the Energy Research, Development, Demonstration, and Deployment (ERD3) Policy Project at the Belfer Center of Science and International Affairs of the Harvard Kennedy School of Government. The commentary builds upon work conducted by ETIP that is supported by the William and Flora Hewlett Foundation, the Packard Foundation, the Energy Foundation, the BP Group and BP Alternative Energy.

The authors would also like to thank Melissa Chan and Charles Jones, research fellows in the ERD3 project, Asma Hamdane, our research assistant, Neal Doyle, project coordinator for Managing the Atom, Venky Narayanamurti, William Hogan, and Henry Lee for their help and comments on an earlier draft.

All responsibility for any remaining errors or misjudgments remains with the authors.

\section{CITATION INFORMATION}

(C) 2009 President and Fellows of Harvard College; Printed in the United States of America.

This paper may be cited as: Anadon, Laura Diaz, Kelly Sims Gallagher, and Matthew Bunn. DOE FY 2010 Budget Request and Recovery Act Funding for Energy Research, Development, Demonstration, and Deployment: Analysis and Recommendations. Cambridge, Mass.: Report from the Energy Technology Innovation Policy research group, Belfer Center for Science and International Affairs, Harvard Kennedy School, June 22, 2009. Comments are welcome and may be directed to Laura Diaz Anadon, Kelly Sims Gallagher, or Matthew Bunn at the Belfer Center, Kennedy School of Government, Harvard University, 79 JFK Street, Cambridge, MA 02138.

Cover Image: Half a MW Cadmium Telluride (CdTe) solar array installed at Springerville, AZ Source: National Renewable Energy Laboratory; Tucson Electric 


\title{
DOE FY 2010 Budget ReQuest AND Recovery Act Funding for ERD3
}

\author{
Laura Diaz Anadon, Kelly Gallagher, and Matthew Bunn
}

Summary: The combination of the FY 2010 budget request for the U.S. Department of Energy (DOE) and the energy-related stimulus funds would provide a substantial boost for DOE supported energy research, development, and demonstrations - a doubling over FY 2009, or \$7.2 billion, if we assume that a half of the Recovery Act funds will be available in fiscal year (FY) 2010. The funds from the Recovery Act are available for program managers to begin obligating now, in FY 2009, and DOE is struggling to obligate these funds rapidly, to contribute to economic recovery. But as it takes some time to ramp up most research, development, demonstration, and deployment programs, we have assumed for the purposes of the overall comparison, that the Recovery Act funds are available to program managers in FY 2010 and FY 2011 so that the FY 2010 request plus a portion of the Recovery Act can be compared to the FY 2009 appropriation, the last appropriation based on an initial funding request from the Bush administration. The support for the deployment of energy technologies in the Recovery Act managed by DOE totals \$23.6 billion, which is almost 3 times larger than the $\$ 8.0$ billion that were appropriated for FY 2009. These large funding increases, however, do not guarantee that the United States will finally enjoy a sizeable, predictable, and consistent publicly-funded energy technology innovation effort. The Obama administration should place high priority on ensuring that the expansion of the effort is both efficient and sustainable.

\section{INTRODUCTION}

Improving the menu of energy technology options available to the United States for the near-, medium-, and long-term is essential (Anadon and Holdren 2009). The combination of the energyrelated provisions in the American Recovery and Reinvestment Act (ARRA, also referred to as Recovery Act in this paper) of 2009 and the request for funds for energy research, development, demonstration, and deployment (ERD3) by the Department of Energy (DOE) for FY 2010 are an important step in this direction. ERD3 spending by DOE is only one element of the broader U.S. energy innovation system, but it is a critical piece, for DOE provides the lion's share of available research, development, and demonstration support for a broad range of energy technologies. Hence, this paper focuses on DOE's FY 2010 ERD3 budget, and the complementary funding provided by ARRA. Before turning to those budgets, however, we briefly put our analysis in context.

\section{STRENGTHENING THE U.S. ENERGY INNOVATION SYSTEM}

DOE has already taken major steps to improve the U.S. performance in developing energy technologies and launching them into the market place, going well beyond budgeting. The award of 46 Energy Frontier Research Centers (EFRCs), the creation of eight Energy Innovation Hubs, ${ }^{1}$ the fund-

\footnotetext{
${ }^{1}$ The FY 2010 DOE budget request includes eight Energy Innovation Hubs. The areas of the research of the Hubs would be Solar Electricity (EERE), Energy Efficient Building Systems Design (EERE), Carbon Capture and Storage (FE), Grid Materials, Devices, and Systems,(OE), Extreme Materials (NE), Modeling and Simulation (NE), Fuels from Sunlight (OS), and Batteries and Energy Storage (OS). Each of the Hubs would be funded at $\$ 25$ million per year for 5 years to provide a steady stream of funding, although their renewal after 5 years will not be automatic. For their first year of operation, the Hubs would receive an additional \$10 mil-
} 
ing of the Advanced Research Projects Agency-Energy (ARPA-E), and an effort to coordinate across programs are major positive steps because they will help put the institutional architecture in place to ensure that ERD3 funds are spent efficiently and effectively. According to its first funding opportunity announcement, ARPA-E will support high-risk projects on transformational energy-related technologies that are too risky for industry and the "flexibility to work with companies who do not traditionally work with the Federal Government" (ARPA-E 2009). If designed properly, the Hubs could help break barriers across disciplines and strengthen the integration of basic and applied research to solve priority challenges (Chu 2009). The ARRA provides funding for a wide range of deployment incentives, taking important steps toward aligning "technology push" policies like ERD3 funding with "market pull" policies designed to increase demand for the very technologies that are being developed in the U.S. RD\&D programs. These deployment initiatives range from the extension of production tax credits to the huge expansion of the Weatherization Assistance Program for deployment of home efficiency technologies. Nevertheless, there is much more to be done.

The Obama administration must put in place a comprehensive strategy that promotes energy innovation in both the public and private sectors, taking advantage of the strengths of each. Such a strategy must: begin with getting the prices right, including putting a substantial price on carbon emissions; allocate resources across a sensible portfolio of energy technologies to meet the principal energy challenges facing the United States; cover the entire spectrum of innovation from basic research through demonstration and deployment (and in particular to ensure that new technologies are not left to wither in the "valley of death" between initial invention and commercial deployment); manage cooperation and competition internationally; and ensure that appropriate institutions and policies are in place for each stage of the needed innovations and that these institutions (e.g. ARPA-E, the Hubs, the National Labs) and policies will work in an integrated manner (Anadon et al. 2009).

DOE will have to develop new approaches to making decisions concerning how and when support for any particular technology should shift from research to development, and from development to demonstration or deployment, and how the related programs should interact. Given the pace at which the ARRA funds must be spent, it is inevitable that a substantial fraction of those funds will be used outside of DOE, thus, DOE will have to decide quickly on how best to use partnerships and other transactions with the private sector and academia. DOE will also have to define how best to integrate the roles of the public and private sectors and of academia.

Deployment support poses a particularly vexing problem, as deployment programs tend to be expensive and prone to pork-barrel politics. The Obama administration and Congress will have to develop a sound strategy for deployment support that is not simply Congress or DOE “picking winners," but that nevertheless tailors the type of support most needed for different types of technologies, and that is designed to be phased out fairly quickly as technologies become economic (or fail to become economic). One way to design this strategy would be for the administration or DOE to create a commission to work on developing this strategy so that it will be in place when the funds from the Recovery Act are not longer available to support near-term innovation in energy technologies.

Our recommendation to establish a commission to develop an energy technology innovation strategy parallels the suggestions made by Ogden, Deutch and Podesta in 2008 to create an interagency Energy Innovation Council to develop a multiyear National Energy RD\&D strategy for the United States (Ogden, Podesta, and Deutch 2008), and by our February 2009 recommendation that the U.S. government should develop, publish, and implement a comprehensive U.S. energy innova-

lion (bringing up the total for the first year of operation to $\$ 35$ million) for renovation, equipment and instrumentation (Chu 2009). 


\section{Figure I: Energy RD\&D funding by DOE between 1978 and the FY 2010 request, including ARRA funds*}

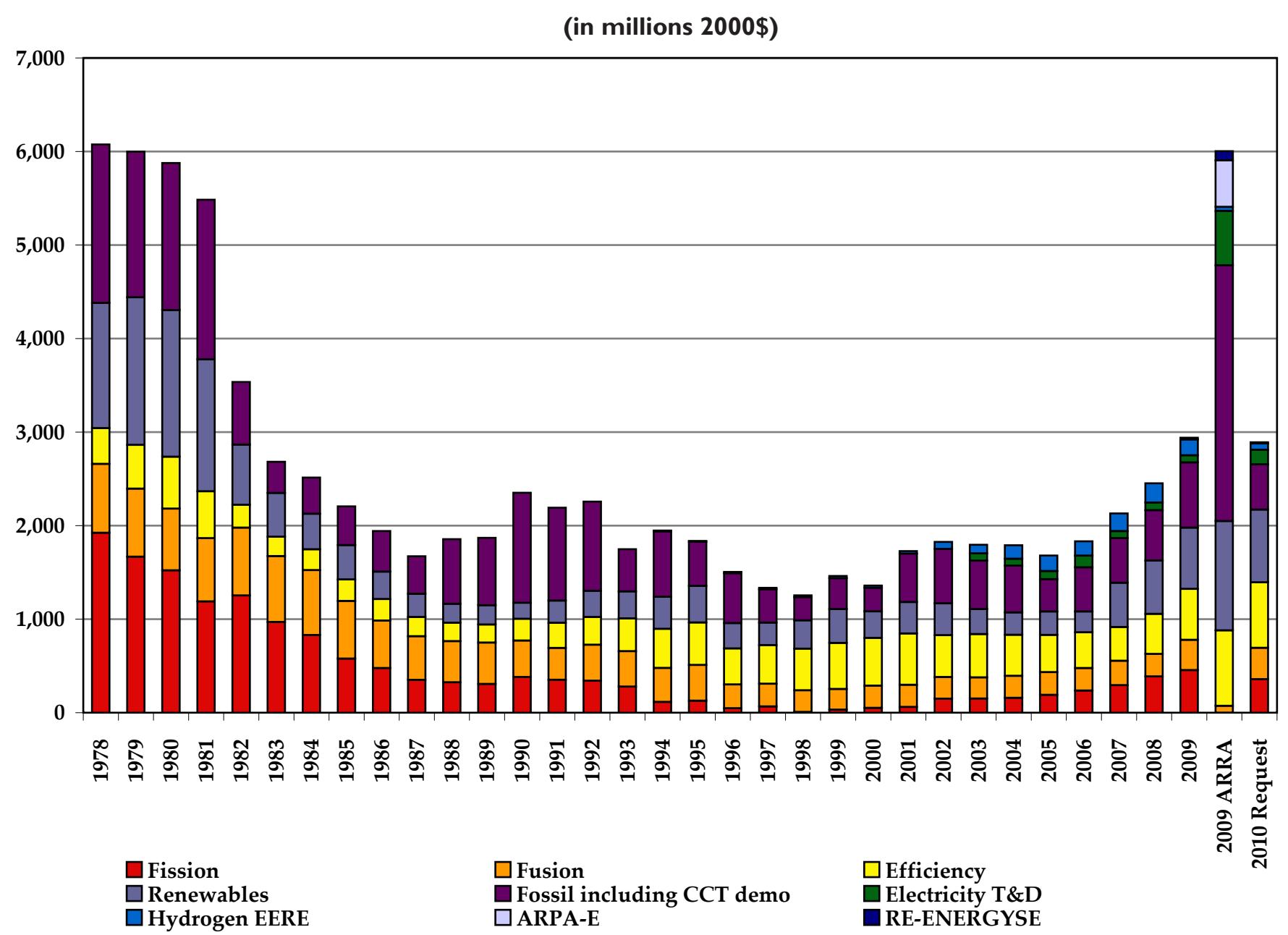

*Figure I does not include funds for the EFRCs, Basic Energy Sciences, or the NSF. The nuclear fission figures do not include funding for nuclear facilities (e.g. Idaho facilities management, or radiological facilities management), because because historically, a substantial fraction of this funding has gone to activities that were not directly related to RD\&D on new nuclear energy technologies. As this funding is becoming more important to nuclear energy RD\&D, we will incorporate nuclear facilities funding in future editions of the budget database (Gallagher, Anadon 2009)

tion strategy (Anadon et al. 2009). The strategy should also address the need to fund and manage large scale demonstration efforts, and to define the role of (and coordinate) international cooperation on energy technology innovation.

\section{THE FY 2010 ERD3 REQUEST IN HISTORICAL CONTEXT}

Figure 1 highlights the funds for energy research, development, and demonstration (ERD\&D) that would be allocated to various energy technology categories if Congress approved the FY 2010 budget request. ${ }^{2}$ The ARRA appropriated twice the enacted FY 2009 energy RD\&D budget from DOE, or about $\$ 6$ billion, to ERD\&D. As indicated by the funding opportunity announcements

${ }^{2}$ The underlying data in the figures presented on this paper can be found in the database that accompanies this paper (Gallagher and Anadon 2009). This database includes DOE funding for energy technology inno- 
(FOAs) that have been released so far, these funds would be spent over the next two to five years. ${ }^{3}$ As shown in Figure 1, the allocation of ERD\&D funds by technology area in the Recovery Act is markedly distinct from that in the FY 2010 request. This is because the proposed FY 2010 budget was devised so as to "complement funds provided by the Recovery Act" (DOE 2009a). As described in detail below, the FY 2010 request would significantly expand RD\&D support for renewable energy and low-carbon energy supply, energy efficiency, and smart grid technologies compared to the FY 2009 appropriation.

In the next sections we detail the main new initiatives and changes by technology area, starting with renewable energy, followed by energy efficiency, hydrogen technology, fossil energy, transmission and distribution, nuclear energy, basic energy sciences, ARPA-E and RE-ENERGYSE, and deployment support.

The emphasis throughout the Recovery Act is on getting the funds into the economy quickly, so that they can contribute to economic recovery. ${ }^{4}$ DOE plans to "obligate" $50 \%$ of its $\$ 38.7$ billion in Recovery Act funding by Labor Day 2009, and spend 70\% by September 2010 (Energy Washington Week 2009). This does not necessarily imply that 70\% of the ERD\&D and deployment funds will be spent by that date. To get an approximate idea of the increase in overall ERD\&D and deployment funding between the FY 2009 appropriation, the last appropriation based on an initial funding request from the Bush administration, and the Recovery Act and the FY 2010 request, we have assumed that the Recovery Act funds will be spent evenly between FY 2010 and FY 2011. The reason for this is that, although the funds from the Recovery Act are available for program managers now, it takes time to ramp up programs. None of our technology-specific analysis, conclusions or recommendations, however, depend on this assumption.

\section{RENEWABLE ENERGY}

Increasing support for renewable energy RD\&D was clearly one of the top priorities of this administration's budget request and the Recovery Act. On top of ARRA, which dedicated nearly $\$ 1.5$ billion for renewable energy research, development, and demonstration (RD\&D), the FY 2010 request would allocate $\$ 976$ million for renewable energy RD\&D. The amount allocated for renewable energy RD\&D for FY 2010 would itself represent a 20\% increase over the enacted budget for FY 2009. ${ }^{5}$ It is notable that the enacted FY 2009 budget was \$250 million greater than the FY 2009 budget request, although a large part of the increase was due to the \$141 million dedicated to congressionally directed projects.

vation from the creation of DOE in 1978 until today. The latest version of the database can be found in our website: www.energytechnologypolicy.org.

${ }^{3}$ For example: the Ground Source Heat Pumps FOA from the Geothermal Technologies Program indicates periods of performance for its different topic areas of up to 1 year and up to 5 years; the High Penetration Solar Deployment FOA has 3 phases of 12 months each; the Smart Grid demonstrations will have project periods between 3-5 years; the Wind University R\&D Consortium award will have a performance period of up to 2 years.

${ }^{4}$ The section of ARRA's Division A, Title IV corresponding to DOE (H. R. 1-24 to H. R. 1-34) does not specify by when all funds must be spent. The temporary program for rapid deployment of renewable energy and electric power transmission projects (Section 1705, also know as the "temporary loan guarantee program") is one exception: ARRA specifies that the program may make guarantees for projects that commence construction no later than September 30, 2011.

${ }^{5}$ The total amount for renewable energy RD\&D used for the comparison between FY 2009 appropriations and the FY 2010 request includes funding for the research programs, facilities, policy and management, and congressionally directed projects. 


\section{Figure 2: Breakdown of DOE funding for renewable energy RD\&D programs between 1998 and the 2010 request (including funding in the ARRA 2009)}

(in millions 2000\$)

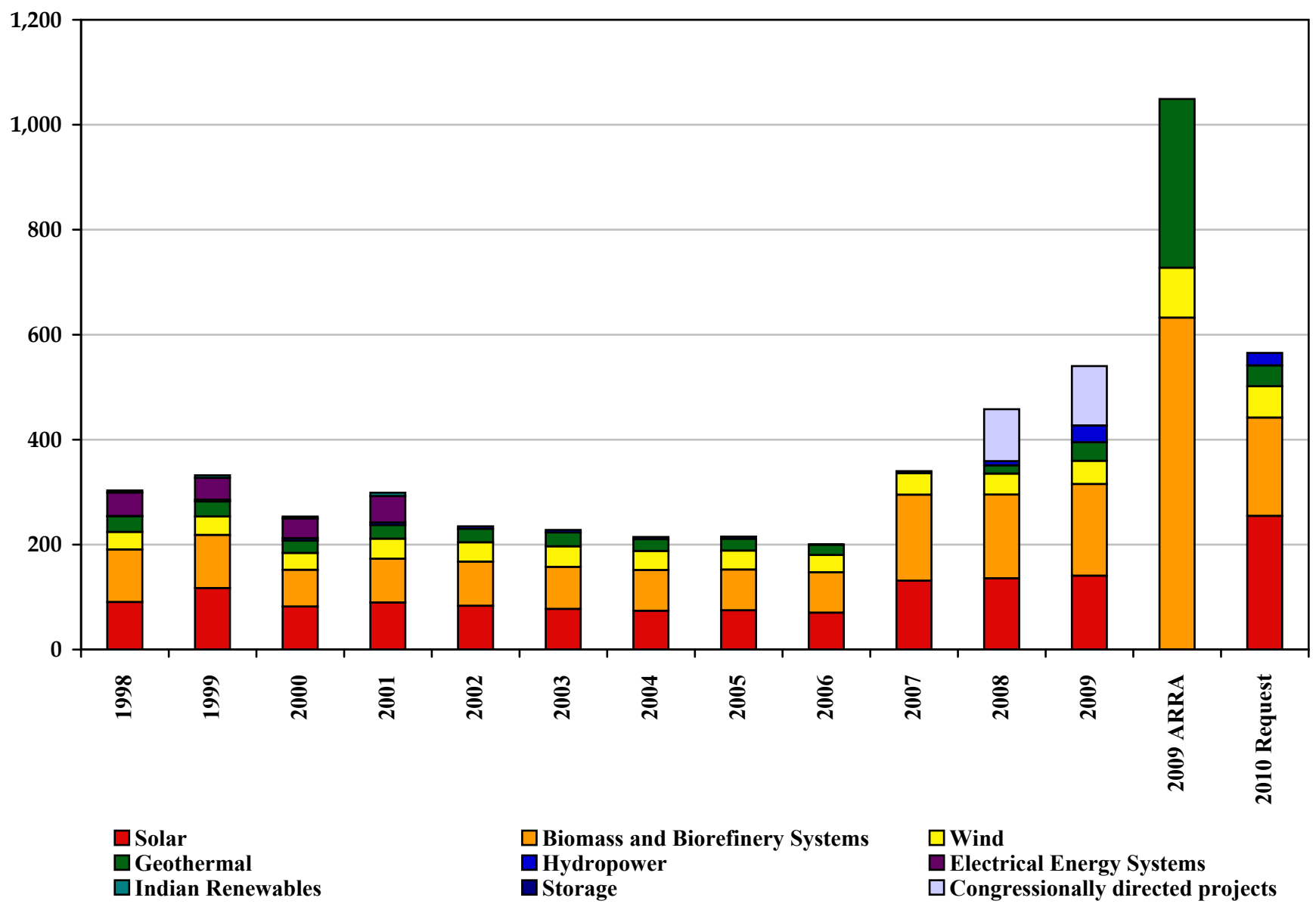

The creation of the solar electricity Energy Innovation Hub may make a substantial contribution to smoothing out barriers across disciplines and technology development stages, thereby helping to incorporate scientific breakthroughs in novel technologies more rapidly. The increases in funding for all renewable technologies, in particular for areas such as off-shore wind, solar thermal, and geothermal energy, are also positive aspects of the FY 2010 request.

The detailed FY 2010 budget also indicates that \$951 million from the Recovery Act will be available for energy efficiency and renewable energy (EERE) "R\&D" according to the Statistical Table, and for EERE "RDD\&D" (which we refer to as RD3 in this paper) according to the detailed justification. The authors are not aware of comprehensive information detailing the ways in which these funds will be spent; for example, whether they will be spent mainly in deployment or in RD\&D, or whether the allocation will be weighted towards EERE projects. It is important to note that we included these funds in the energy efficiency RD\&D category in the database, and thus, the funding for energy efficiency in ARRA shown in Figure 1 represents an upper bound, and the renewable energy amount represents a lower bound. 
A comparison between the funding for programs within the renewable energy category from the Office of Renewable Energy and Energy Efficiency shows large differences between the mechanisms that DOE used to fund each program. Initially, while the biomass, geothermal and wind programs received large amounts of money from the stimulus package, the expansion of the solar program would be entirely funded by an increase in the usual appropriations process. On May 27 President Obama announced the allocation of \$118 million from the Recovery Act (presumably from the $\$ 951$ million dedicated to EERE R\&D) to accelerate the widespread commercialization of solar technologies (DOE 2009b) (see Figure 2 for a breakdown of the funding for renewable energy RD\&D). The following points describe the sources and uses of funding for the different renewable energy programs:

Solar. The solar energy RD\&D program did not receive any specific funds from the Recovery Act according to the detailed budget request, although it received at least $\$ 118$ million after the FY 2010 request was released. The $\$ 320$ million requested for solar for FY 2010 would represent an $83 \%$ increase over the enacted FY 2009 budget. If the FY 2010 budget is implemented, DOE's solar ERD\&D budget would increase by a factor of 3.9 since FY 2006 in nominal dollars and by a factor of 3.6 in real dollars (this does not include the \$118 million from the ARRA or any other funds from the generic \$951 million EERE RD\&D that may be allocated to solar in the future). The increase would be driven by: a renewed emphasis on concentrating solar power, which would experience a funding increase of a factor of 3 from \$24 million in FY 2009 to \$78 million in FY 2010; ${ }^{6}$ an increase of $\$ 15$ million in funding for the program on systems integration (which received $\$ 12$ million in FY 2009); an increase of $\$ 13$ million for the market transformation activities, which received $\$ 14$ million in FY 2009; and \$35 million for an Energy Innovation Hub focused on converting solar energy to electricity. ${ }^{7}$

Biomass. ARRA allocated $\$ 787$ million for biomass RD\&D. Over $60 \%$ of those funds will fund solicitations for integrated pilot- and demonstration-scale biorefineries, capped at $\$ 25$ million and \$50 million, respectively (DOE 2009c). \$110 million (or 14\% of the total ARRA funds for biomass RD\&D) will support fundamental $R \& D$, and a large fraction of this, $\$ 50$ million, will accelerate the demonstration of algal biofuels. The remainder of the ARRA funds for biomass will accelerate the construction phase of two or more commercial-scale projects (\$176 million) and ethanol research (\$20 million). The biomass program would place a large emphasis on demonstration and commercialization projects, largely due to the near-term demands of the stimulus funds, but not entirely. The FY 2010 request for \$235 million represents an 8\% increase over the FY 2009 appropriation. Most of the increase (\$12 million) would support Feedstock Infrastructure activities, which would have a total funding of $\$ 27$ million. The increase in Feedstock Infrastructure would mainly focus on addressing potential sustainability barriers of energy crops. Notably, if enacted the FY 2010 budget would almost equalize R\&D funding for the Thermochemical and Biochemical Platforms. While in FY 2008 Thermochemical Platform R\&D received \$26 million, or two-thirds of the \$39 million allocated to the Biochemical Platform R\&D, the request for FY 2010 would allocate \$27 million for the thermochemical route and $\$ 31$ million for the biochemical one. The increase in funding for thermochemical conversion R\&D would focus on core technology development and the scale-up of near term options. The implementation of public-private cost-shared pilot, demonstration, and commercial-scale biorefinery projects would receive \$148 million according to the FY 2010 request. The 2009 National Academies entitled ‘Liquid Transportation Fuels from Coal and Biomass: Tech-

\footnotetext{
${ }^{6}$ An important component of the proposed changes to the concentrated solar power program is the allocation of \$12 million for thermal storage.

7 To improve the coordination between agencies and efforts the EERE solar program is working with the Office of Science, the Building Technologies Program and the Federal Energy Management Program on solar $R \& D$ and deployment opportunities, as well as with other agencies such as DARPA, the Bureau of Land Management.
} 
nological Status, Costs, and Environmental Impacts' details some important tasks to that could help determine the role of biomass to manufacture liquid fuels. One recommendation is that DOE and USDA should determine the spatial distribution of potential U.S. biomass supply to obtain better information on the potential size, location, and cost of coal and biomass conversion plants (NAS 2009). Another recommendation of the report is that 'technologies that increase the density of biomass in the field [such as field-scale pyrolysis]... should be developed', as they could facilitate biomass transportation to larger-scale regional thermochemical conversion facilities.

Wind. The ARRA allocated \$118 million to wind RD\&D. The majority of these funds (\$93 million) will be used to support advanced wind energy research. The remaining $\$ 25$ million will be dedicated to a Wind Technology Testing center in Massachusetts. The center will be the first test facility for commercial large blades longer than 50 meters in the United States - Europe already has such facilities. The rationale is that a center may "quicken the creation of large-scale offshore wind power facilities" by attracting companies to design, manufacture, and test blades in the United States (DOE 2009d). According to the FY 2010 request the wind subprogram would receive a RD\&D funding increase of 36\% from \$55 million in the FY 2009 appropriation to $\$ 75$ million in FY 2010. One of the main areas of focus of this increase would be offshore wind activities. The activities characterizing offshore wind resources, identifying offshore wind turbine design requirements, and supporting competitively selected land-based technology development projects would receive $\$ 10$ million. The Systems Integration and Technology Acceptance programs, which are complements to the technology viability programs, would also receive funding increases.

Geothermal. The Recovery Act included an unprecedented $\$ 400$ million of funding for geothermal energy, \$350 million of which will support: the validation of innovative exploration technologies; geothermal energy production from low temperature resources, coproduced fluids from oil and gas wells, and geopressured resources; and development, collection, and maintenance of geothermal data (EERE 2009). The FY 2010 budget request for geothermal RD\&D was \$50 million, $\$ 6$ million greater than that in the FY 2009 appropriation. These funds would expand the scope of R\&D in reservoir stimulation, fracture mapping, fluid circulation, and demonstration site analysis for Enhanced Geothermal Systems. The program would also support creating a web-based, public geothermal database for resource, power plant, and institutional data. Such a database could make an important contribution to leveraging private sector investment in the medium term.

Water power. Funding for the water power program would decrease by $25 \%$ from $\$ 40$ million in the FY 2009 appropriation to $\$ 30$ million in FY 2010. The marine and hydrokinetic technology activities would focus on the development and deployment of in-water prototypes and projects, testing and modeling of deployed technologies, development of new and innovative technologies, resource assessments, environmental impact studies, and cost analyses. The hydropower activities would support a full assessment of domestic existing hydropower assets and developing more efficient and environmentally friendly hydropower turbines for the commercial market.

The breakdown of the FY 2010 request by RD\&D technology program is 45\% for solar, 33\% for biomass, $11 \%$ for wind, $7 \%$ for geothermal, and $4 \%$ for water power.

The breakdown of congressionally directed projects in FY 2009 was $22 \%$ for solar, 56\% for biomass, $8 \%$ for wind, $7 \%$ for geothermal, and $6 \%$ for water power. The $\$ 141$ million appropriated in FY 2009 for this purpose represents a 16\% increase over FY 2008 levels. 


\section{ENERGY EFFICIENCY}

Another area to which the Recovery Act and the FY 2010 request gave high priority were investments in energy efficiency RD\&D. The $\$ 881$ million requested for energy efficiency RD\&D for FY 2010 would represent a 30\% increase over the enacted FY 2009 budget. $^{8}$ This amount included a $70 \%$ increase in the funding for the building technologies RD\&D program, which is also a positive development, as it reflects more accurately the importance of the buildings sector in the energy system and the need for government support given the dispersed nature of the private sector efforts in buildings RD\&D. The FY 2010 request would also allocate $\$ 347$ million for efficiency deployment programs. In addition, as indicated above, the Recovery Act allocated a maximum of \$951 million for energy efficiency R\&D (or "RDD\&D" depending on where one looks) and $\$ 15.2$ billion for deployment programs related to energy efficiency. Unlike the renewable energy programs (e.g. solar, geothermal), which received several specific amounts of Recovery money for RD\&D, to our knowledge only $\$ 50$ million of RD\&D funds from the recovery package have been allocated to a particular program (industrial technologies) in the area of energy efficiency.

Figure 3 indicates that the FY 2010 RD\&D energy efficiency request is similar to the enacted FY 2009 budget (when one includes the $\$ 73$ million in earmarks directed by Congress in FY 2009). Below we describe the main features of the FY 2010 request and the Recovery Act.

Vehicle technologies. The FY 2010 request includes \$333 million for the vehicle technologies (VT) program, a 22\% increase in funding from the $\$ 273$ million appropriated in FY 2009. About $65 \%$ of the funding increase would expand the hybrid electric systems subprogram from \$126 million to $\$ 165$ million. Energy storage R\&D would make up $47 \%$ of the cost of the hybrid electric systems subprogram, or $\$ 77$ million. This important program would receive $\$ 8$ million more than it received in FY 2009. The long-term effort of the EERE VT energy storage activities is focused on developing advanced materials for the next generation of energy storage technologies, while the nearer-term technology development is through the United States Advanced Battery Consortium, which functions through $50 \%$ cost-shared subcontracts with the private sector. The other two major components of the vehicle technologies program, advanced combustion engine R\&D and materials technology, would experience funding increases around $40 \%$ to $\$ 58$ million and \$55 million, respectively.

Building technologies. With a 70\% increase from \$140 million enacted for FY 2009 to \$238 million requested for FY 2010, the building technologies (BT) RD\&D program would receive the largest relative increase. The five components of the program - residential buildings integration, commercial buildings integration, emerging technologies, technology validation and market introduction, and equipment standards and analysis - would receive funding increases ranging from $21 \%$ for commercial buildings program, to $111 \%$ for the emerging technologies. The commercial buildings program grew rapidly from $\$ 12$ million (or half of the funding that was directed to the residential buildings program) in FY 2008 to $\$ 33$ million in FY 2009 (or 50\% more than the residential buildings program). Notably, if the FY 2010 request is enacted, the commercial and residential buildings integration programs would be equally funded in FY 2010, and the emerging technologies (longerterm) research program would double its funding to \$93 million when compared to FY 2009. Most of the increase (\$35 million) would support an Energy Innovation Hub in Energy Efficient Building Systems. The building technologies request is in line with the American Physical Society 'Think Efficiency' report, which recommended an increase in total funding to $\$ 250$ million - although they

\footnotetext{
${ }^{8}$ This increase considers funds for RD\&D programs as well as funding for program direction and program support. The last two items are not included in Figure 3.
} 


\section{Figure 3: Breakdown of DOE funding for energy efficiency RD\&D between 1998 and the FY 2010 request (including funding in the ARRA 2009)}

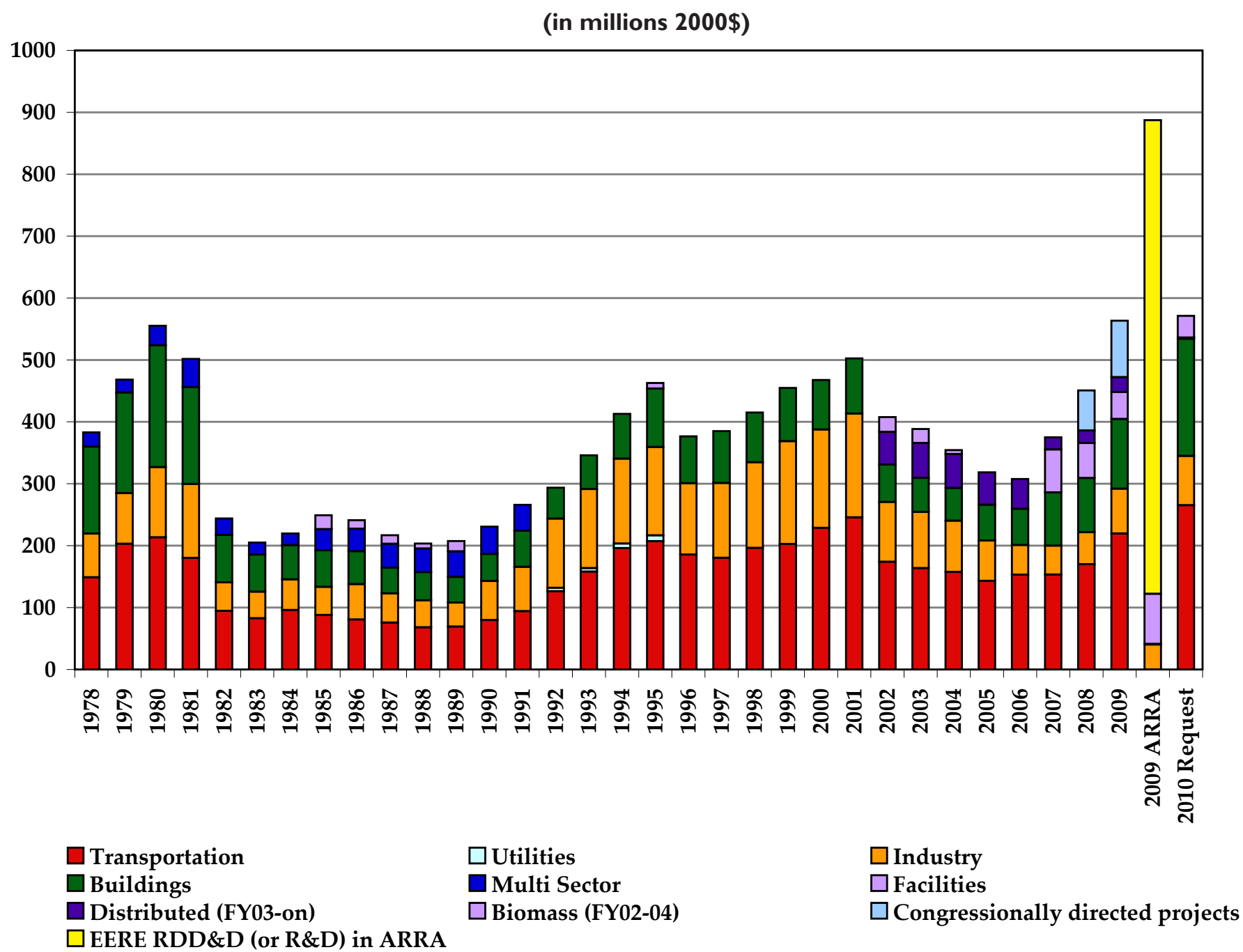

recommended that the increase would take place over a period of 3-5 years - and a greater longterm RD\&D effort (APS 2008).

Industrial technologies. The FY 2010 budget request would increase funding for the industrial technologies program from $\$ 90$ million in FY 2009 to $\$ 100$ million. The industry-specific activities, which deal with challenges from the forest and paper products, steel, aluminum, metal casting, glass, and chemicals industries, would receive a slight cut of $\$ 3$ million to $\$ 13$ million, and the cross-cutting activities an increase of \$13 million to \$87 million over the budget enacted in FY 2009. The Recovery Act also included \$50 million for industrial technology R\&D.

In total energy efficiency RD\&D received $\$ 73$ million of congressionally directed projects, a 39\% over the FY 2008 level. The allocation by project type was 17\% for vehicle technologies, $21 \%$ for building technologies, $16 \%$ for industrial technologies, $2 \%$ for weatherization, and the remaining $45 \%$ for cross-cutting energy efficiency topics.

The large increases in RD\&D for building technologies and the ramping up of long-term efforts aside, there have not been many significant changes to the ERD\&D portion of DOE's RD\&D 
energy efficiency activities. The energy-efficiency-related deployment programs, however, have increased even more dramatically. As shown in Table 1-which indicates the program type, year of enactment, and size-FY 2008 and FY 2009 appropriations included $\$ 0.8$ billion and $\$ 8.7$ billion for energy efficiency deployment, respectively, and the Recovery Act included $\$ 15.2$ billion.

\section{HYDROGEN TECHNOLOGY}

The FY 2010 budget request would cut funding for fuel cells in EERE by $62 \%$ from $\$ 181$ million to $\$ 68$ million in FY 2010. In justifying this large cut, Secretary Chu said that "to get significant deployment [of hydrogen-fueled transportation], you need four significant technological breakthroughs" - in efficient hydrogen production, in hydrogen storage, in fuel cells, and in the distribution infrastructure. Chu therefore judged hydrogen to be a technology for "the distant future" (Bullis 2009).

The focus of EERE's Fuel Cell program would shift to resolving critical technical barriers through research on materials R\&D for fuel cell stack components, such as membranes, catalysts, electrodes, and on modes of operation. Funding for several areas of research, including hydrogen production and delivery (which received \$10 million in FY 2009) and hydrogen storage (which received \$52 million in FY 2009) would be deferred in alignment with DOE's belief that hydrogen technologies are not likely to penetrate the market in the near term.

Funding for distributed fuel cells systems would be cancelled according to the FY 2010 request, presumably because the recovery package included \$13 million for this purpose; the program had received \$10 million in FY 2009.

In short, hydrogen research would be more focused on critical pathway components for fuel cells and abandon the area of hydrogen storage, thereby reducing the cost of the program.

\section{FOSSIL ENERGY}

The FY 2010 budget request would direct $\$ 607$ million to fossil energy RD\&D. This is a 30\% decrease from the $\$ 886$ million appropriated for fossil energy RD\&D in FY 2009. The cause of this apparent decrease was the fact that the Recovery Act included \$3.5 billion for fossil energy RD\&D. In fact, if we assumed that half of the fossil RD\&D ARRA funds would be spent on the first year, then DOE would have to spend $\$ 2.3$ billion in fossil energy RD\&D in FY 2010, a 166\% increase over FY 2009. When ARRA and the FY 2010 request are considered together, fossil energy (mainly CCS) would receive of one of the larger increases compared to FY 2009 funding.

Coal RED. The coal R\&D category, in which we include the clean coal power initiative and the fuels and power systems sub-program - and exclude the carbon sequestration research activity would receive \$224 million for FY 2010 from the normal appropriations process and \$820 million from the recovery package (it received \$542 million in FY 2009). Coal R\&D includes advanced IGCC, innovations for existing plants, advanced turbines, and some fuel cell research.

The Fuels activity aims to improve environmentally and economically the conversion of coal to high-purity hydrogen for electric power generation turbines and ultra-pure hydrogen for the transportation sector (e.g. for proton exchange membrane fuel cells). ${ }^{9}$ It is notable that no funding

\footnotetext{
${ }^{9}$ The fact that the coal R\&D program mentioned the fact that one of the applications of ultra-pure hydrogen may be its use for the transportation sector is not necessarily a contradiction of Secretary Chu's statement
} 
would be allocated for synthetically producing natural gas, coal to liquids research, on-board hydrogen storage, or mobile hydrogen utilization. The program would experience a severe cut from \$25 million in FY 2009 to \$15 million in FY 2010.

The Fuel Cells activity would receive \$54 million and focus on central station and distributed generation applications, or $\$ 4$ million less than in FY 2009, and would be focused on enabling the generation of efficient, cost-effective electricity from domestic coal with near-zero atmospheric emissions of $\mathrm{CO}_{2}$ and air pollutants in stationary applications. This cut is consistent with the overall direction taken by DOE in the area of hydrogen technology. Finally, the Advanced Research effort, which serves as a bridge between basic and applied research - will add two new areas to its activities. The first will be research on innovative carbon capture technological breakthroughs for new and existing plants from air, and the second area will be research on novel devices for electrochemical energy conversion and storage.

Carbon Sequestration. Carbon sequestration research would receive a $\$ 30$ million increase from $\$ 150$ million in FY 2009 to \$180 million in FY 2010. The research is aimed at developing technologies to separate, capture, transport, and sequester $\mathrm{CO}_{2}$ and a methodology capable of predicting $\mathrm{CO}_{2}$ storage capacity in geologic formations to within 30 percent of actual storage capacity. In addition, the ARRA allocated just under $\$ 1.6$ billion for a carbon capture competitive solicitation. The ARRA would also fund carbon capture and storage demonstration projects with $\$ 1$ billion, which will be directed to FutureGen. Given the new availability of ARRA funds, DOE has chosen to restart the FutureGen effort, and Secretary Chu has described the project as "a flagship facility to demonstrate carbon capture and storage at commercial scale" (DOE 2009e). ${ }^{10}$ The carbon sequestration research effort also includes \$35 million for a Carbon Capture and Storage Energy Innovation Hub. The Innovation Hub would enable fundamental advances and discovery of novel and revolutionary capture/separation approaches to dramatically reduce the energy penalty and costs associated with $\mathrm{CO}_{2}$ capture through computational and experimental studies aimed at better understanding surface interactions of $\mathrm{CO}_{2}$ and other gases, novel solvents/sorbents, and chemical, physical, and biological separation approaches. The Carbon Sequestration Regional Partnerships (CSRP), also funded by the carbon sequestration activities, consists of seven Regional Partnerships. In FY 2010 nine projects within Phase III (development) of the partnerships will carry out large volume sequestration tests -1 million metric tons of $\mathrm{CO}_{2}$ would be injected at two or more sites at a rate of 1 million metric tons of $\mathrm{CO}_{2}$ equivalent per year per site. ${ }^{11}$

Petroleum and Gas. The petroleum program would receive no funds in FY 2010, or \$5 million less than in FY 2009. The gas program would receive an increase of $\$ 5$ million over the $\$ 20$ million it received in FY 2009. The gas program would be entirely focused on technologies to find and produce gas hydrates. ${ }^{12}$ The natural gas program would conduct research domestically and with

regarding the long-term nature of hydrogen as a transportation fuel. The Fuel sub-program's research may serve for transportation's goals in the future, but the program would receive a significant cut from $\$ 25$ million in FY 2009 to \$15 million in FY 2010 and the language on stationary applications is stronger than in previous years.

${ }_{10}$ On June 122009 Secretary Chu announced a provisional agreement between DOE and the FutureGen Alliance. DOE will issue a Record of Decision in mid-July 2009, and the Alliance will carry out a set of activities between then and early 2010. At that point a decision to move forward or discontinue the project will be made; both parties agree that the preferred outcome is to continue. The $\$ 1$ billion represents DOE's total anticipated financial contribution to FutureGen from the Recovery Act (DOE 2009e).

${ }^{11}$ In FY 2010, under CSRP, $C_{2}$ capture projects, awarded through a FY 2009 solicitation, will be starting and progressing in the area of pre-combustion $\mathrm{CO}_{2}$ capture including novel concepts, system analysis, benchscale, and pilot-scale projects to reduce the capture cost.

12 This novel potential resource is located in Alaska, the Gulf of Mexico and other offshore locations of the U.S. It is estimated that if only 1 percent were economically producible, the U.S. could triple its natural gas resource base. 
foreign scientists through bilateral agreements. This is an important area of international cooperation that should continue to be pursued.

Unlike in the areas of energy efficiency and renewable energy, which experienced increases in the size of congressional appropriations from FY 2008 to FY 2009, funding for congressionally appropriated projects in fossil energy fell from \$47 million in FY 2008 to \$44 million in FY 2009. These projects range from work on fuel cells, carbon sequestration, shale oil upgrading, and heavy oil. The main question about the fossil energy research remains with the management of CCS demonstration efforts, including FutureGen. As we and others have argued elsewhere (Anadon et al. 2009), pilot, demonstration, and commercialization stage innovation requires procurement, funding, and decision rules similar to those of private sector enterprises, so that information about genuinely commercialized technology is generated to inform policymakers and the business community. Demonstration projects, managed credibly for private sector, are important for technologies like CCS, which require large upfront costs and the integration of a complex system.

Finally, it is surprising that coal-to-liquids R\&D was zeroed. The recent NAS report on Liquid Transportation Fuels (NAS 2009) recommends developing "detailed scenarios of market penetration rates of biofuels, coal-to-liquid fuels, and associated coal supply options...to clarify hurdles and challenges to achieving substantial effects on U.S. oil use and $\mathrm{CO}_{2}$ emissions" and that a first step could be to build "a few coal-to-liquid plants and coal-and-biomass-to-liquid plants" that "could serve as sources of $\mathrm{CO}_{2}$ for a small number of CCS demonstration projects." Given the potential role of coal-to-liquids and coal-and-biomass-to-liquids in the future of the U.S. transportation sector identified in the report, ${ }^{13}$ it seems that at least a modest amount of funding should be dedicated to exploring these opportunities within DOE, always in the context of climate mitigation, i.e. including carbon capture and storage considerations in any analysis, design, or demonstration. In the 'Deployment Support' section we briefly discuss the opportunities in DOE's loan guarantee authority for innovative clean coal technologies that may serve to partially support some of the large-scale projects suggested by the NAS report, but we are not aware of funds that would be directed to the detailed scenario analysis of market penetration and coal supply options or to any R\&D that may be required to ready these technologies for demonstration and deployment.

\section{TRANSMISSION AND DISTRIBUTION}

The work on electricity transmission and distribution (T\&D) managed by the Office of Electricity Delivery and Energy Reliability (OE) would also be significantly expanded in FY 2010. The \$195 million requested for FY 2010 is roughly twice the FY 2009 appropriation, the largest percentage increase for any major area of energy technology. ${ }^{14}$ Funding for research and development would increase by more than a factor of 3 from \$55 million in FY 2009 to \$174 million for FY 2010 (the remainder of the funds are dedicated to program direction). The OE R\&D program will be completely redefined and divided into four new areas: clean energy transmission and reliability, smart grid, energy storage, and cyber security.

\footnotetext{
${ }^{13}$ The report concludes that coal-and-biomass-to-liquid fuels by thermochemical conversion could produce up to 60 billion gallons of liquid fuels per year on a gasoline-equivalent basis (or one-fifth of total crude oil and petroleum products consumed in the United States in 2008 according to the U.S. Energy Information Administration) when combining coal and biomass at a ratio of 60:40 on an energy basis at an estimated cost of $\$ 100 / \mathrm{bbl}$ (\$ per barrel) of gasoline equivalent with carbon capture and storage (NAS 2009). Coal-to-liquid fuels by chemical conversion were estimated to have a cost of $\$ 60 / \mathrm{bbl}$ of oil equivalent when combined with CCS - life-cycle emissions of $\mathrm{CO}_{2}$ would be similar to those of conventional gasoline.

${ }^{14}$ By major area we mean energy efficiency, renewable energy, fusion, fission, transmission and distribution, and hydrogen.
} 
With $\$ 42$ million requested for FY 2010, the clean energy transmission and reliability research effort will focus on next-generation cables and conductors and on improving our understanding of the power system.

The smart grid research activities would include \$35 million for an Energy Innovation Hub on Grid Materials, Devices, and Systems to develop new "smart" materials for conductors, insulators, power electronics and other elements of the electric system in collaboration with the Office of Science and EERE, and $\$ 32$ million for smart grid R\&D on power electronics and smart material-based sensors.

As with the solar and vehicle technologies programs, funding for energy storage would increase - in this case from \$7 million in FY 2009 to \$15 million in FY 2010. The storage research program would coordinate with basic research in the new Energy Frontier Research Centers, funded by DOE's Office of Science, and work on batteries, electrolytic capacitors, fly wheel systems, and compressed air energy storage

Given that according to the FY 2010 detailed justification of OE cyber security has emerged as "one of the Nation's most serious infrastructure protection issues," the newly created program for cyber security for energy delivery systems would receive a substantial \$50 million in FY 2010.

The Recovery Act complements the R\&D programs described above with funding for demonstration and deployment of smart grid innovations. These programs were authorized by the Energy Independence and Security Act of 2007 and include \$700 million for Smart Grid Regional Demonstrations under Section 1304, and almost \$3.4 billion for a federal matching fund on smart grid investments under Section 1306. Although the Recovery Act includes some positive deployment incentives that could help accelerate the introduction of developments resulting from the RD\&D programs, it is important to note that it is a very short term program, and that typically for innovation policy to bear fruit, a longer term time frame is generally needed.

The proposed funding situation for energy storage RD\&D is worth highlighting. EERE's solar program and vehicle technologies programs would receive \$12 million for thermal energy storage and $\$ 77$ million for energy storage (mainly for research on batteries), respectively. OE would receive $\$ 15$ million for storage focused on batteries, capacitors, flywheels, and compressed air storage. Finally, the energy storage Innovation Hub from the Office of Science would receive $\$ 35$ million. In total, various types of energy storage RD\&D would receive \$139 million in DOE's FY 2010 request. Given the importance of improving energy storage technologies in the power and transportation sectors, Congress should consider increasing the funds devoted to energy storage for mobile and stationary applications, and DOE should ensure that there is effective coordination between Basic Energy Sciences (BES, from DOE's Office of Science), EERE, the Office of Energy Delivery and Electricity Reliability, and other departments and institutions (e.g. NASA and ARPA-E).

Even though there may be scope for more RD\&D in storage, the combination of the program already in place and the Advanced Technology Vehicles Manufacturing Loan Program (discussed in the section on "Deployment Support") has the potential to improve U.S. competitiveness in storage technologies, and in particular in batteries. 


\section{NUCLEAR ENERGY}

The Obama administration has asked for $\$ 449$ million for nuclear fission R\&D in FY 2010, a 21\% decrease over the $\$ 566$ million it received in FY 2009. ${ }^{15}$ The changes represent a downscaling of near-term fuel reprocessing research and development, as called for by many groups (NCEP 2004, 99; MIT 2003, 75; APS 2005; NRC 2007; Bunn 2007), and a reduction in federal support for near-term power reactor deployment activities that can be carried forward by private industry.

The Nuclear 2010 program would be substantially scaled back, from \$178 million in FY 2009 to \$20 million in FY 2010. (The FY 2009 request had been even higher than the appropriation, at \$241 million.) The Obama administration concluded that cost-shared activities with industry could be phased out, because the industry partners have "developed satisfactory equity and momentum in the design and certification and licensing" of reactor designs now being prepared for their first deployment-known as "Generation III" or "Generation III+" reactors - "that they are well positioned to complete these activities as a fully private venture." The request would give the "Generation IV" program-designed to explore new reactor and fuel cycle concepts that might be deployed over the next three decades - a slight increase from \$180 million in FY 2009 to \$191 million in FY 2010.

While the Bush administration had focused the Generation IV program almost entirely on development of a very high temperature reactor (VHTR) with gas coolant, and was planning for a deployment decision in 2011, the FY 2010 request focuses on a broader array of potential future nuclear fission technologies and no longer mentions a 2011 target. The goal is described as being "scientific R\&D to improve further the safety performance, security, proliferation-resistance, and lower costs of advanced reactor concepts that could be available in the 2030 timeframe;" the budget also expresses the hope that some of the R\&D on advanced systems will also provide knowledge that will help extend the operating life of existing light water reactors. The program would include a \$35 million Modeling and Simulation Energy Innovation Hub to better integrate basic and applied research by providing and validating advanced modeling and simulation tools.

The request proposes to cancel the Nuclear Hydrogen Initiative, which received $\$ 8$ million in FY 2009. DOE argues that its hydrogen work should focus on higher priority nearer-term transportation technology research, as highlighted by the hydrogen fuel cell program in EERE.

The FY 2010 request renames the Advanced Fuel Cycle Initiative to the broader "Fuel Cycle Research and Development," and redirects it to focus on "long-term, science-based R\&D of technologies with the potential to produce beneficial changes to the way in which the nuclear fuel cycle, and particularly nuclear waste, is managed" rather than on near-term deployment of reprocessing and fast reactors. At the same time, however, DOE proposes to increase this program's funding by $32 \%$, from $\$ 145$ million in FY 2009 to $\$ 192$ million in FY 2010. This funding includes a \$35 million Energy Innovation Hub for Extreme Materials to obtain a fundamental understanding of materials behavior under extreme radiation exposures and very high temperatures. The hub would focus on some of the difficulties involved in fabricating fuels to withstand very high radiation doses and temperatures, and making such fuels and irradiation targets from higher actinides and fission products.

The budget justifications make clear that the Obama administration has not yet formulated a clear plan for fission research and development. Given that situation, it is difficult to justify the high funding level requested. We believe that an effective nuclear research and development pro-

\footnotetext{
${ }^{15}$ As noted earlier, these figures do not include funding that is intended for maintaining already-existing facilities, along with a portion of the program direction funds proportional to the fraction of total funding devoted to maintaining facilities. The total nuclear energy R\&D request, including these facilities maintenance accounts, is $\$ 761$ million, a $\$ 31$ million (4\%) cut from the FY 2009 appropriation.
} 
gram could be pursued with a smaller budget - perhaps something in the range of $\$ 350$ million, as we previously recommended (Anadon et al. 2009).

Perhaps the biggest policy change related to nuclear energy is the Obama administration's decision to terminate the Yucca Mountain nuclear waste repository program, leaving the country with no plan for long-term disposition of spent nuclear fuel and nuclear wastes. DOE proposes to cut the nuclear waste disposal budget by 32\%, from \$288 million in FY 2009 to \$197 million in FY 2010. DOE describes the proposed budget as implementing "the Administration's decision to terminate the Yucca Mountain program while developing nuclear waste disposal alternatives," and argues that the amount requested is "the minimal funding needed to explore alternatives for nuclear waste disposal... and to continue participation in the Nuclear Regulatory Commission (NRC) license application (LA) process, consistent with the provisions of the Nuclear Waste Policy Act."

The FY 2010 request would increase nuclear fusion R\&D by 5\% over the enacted FY 2009 budget, to $\$ 421$ million. Unlike the FY 2009 budget request, the FY 2010 request would fund the U.S contributions to the International Thermonuclear Experimental Reactor (ITER) project.

\section{BASIC SCIENCES,ARPA-E,AND RE-ENERGYSE}

The budget for Basic Energy Sciences would increase by \$105 million to \$1.5 billion in FY 2010 . The increase is greater if one takes into account the $\$ 390$ million allocated to BES from the recovery package. Again, assuming that these funds will be evenly split between FY 2010 and FY 2011, BES funding would increase by $21 \%$ from FY 2009 (see Figure 4). This would put BES on a path to doubling its size in less than 4 years. BES includes funding for two Hubs with themes from the grand energy challenges identified by the Basic Energy Sciences Advisory Council: the direct creation of fuels from sunlight and advanced methods of energy storage. In total these Hubs would receive $\$ 70$ million.

ARPA-E, which was authorized in the America COMPETES Act of 2007 to fill the gaps in the energy innovation pipeline and issued its first Funding Opportunity Announcement in April 2009, will receive $\$ 400$ million from the recovery package and \$10 million from the Energy Transformation Acceleration Fund at the U.S. Treasury. ${ }^{16}$ Appropriations for ARPA-E will, by statute, be distinct from the rest of DOE's budget.

Finally, RE-ENERGYSE, or Regaining ENERGY Science and Engineering Edge, would receive $\$ 80$ million for its higher education activities. This will include up to 200 three-year graduate fellowships in engineering and other fields, 200 postdoctoral fellowships in laboratories devoted to clean energy, and up to 1,000 summer assistantships for undergraduate students.

\section{DEPLOYMENT SUPPORT}

The combination of the Recovery Act and the FY 2010 budget request would also provide large amounts of funds to assist the deployment of energy technologies. Table 1 summarizes the different deployment programs administered by DOE which included appropriations.

\footnotetext{
${ }^{16}$ ARPA-E grants would range between $\$ 0.5$ million and $\$ 10$ million and would be spent over 3 years. ARPAE would fund the best ideas and assemble teams to advance high-risk, high-reward energy research projects that can yield revolutionary changes in how we produce, distribute, and use energy (Chu 2009).
} 


\section{Figure 4: Basic Energy Sciences and RD\&D budgets between FY 1978 and the FY 2010 request (including ARRA 2009 funds)}

(in millions 2000\$)

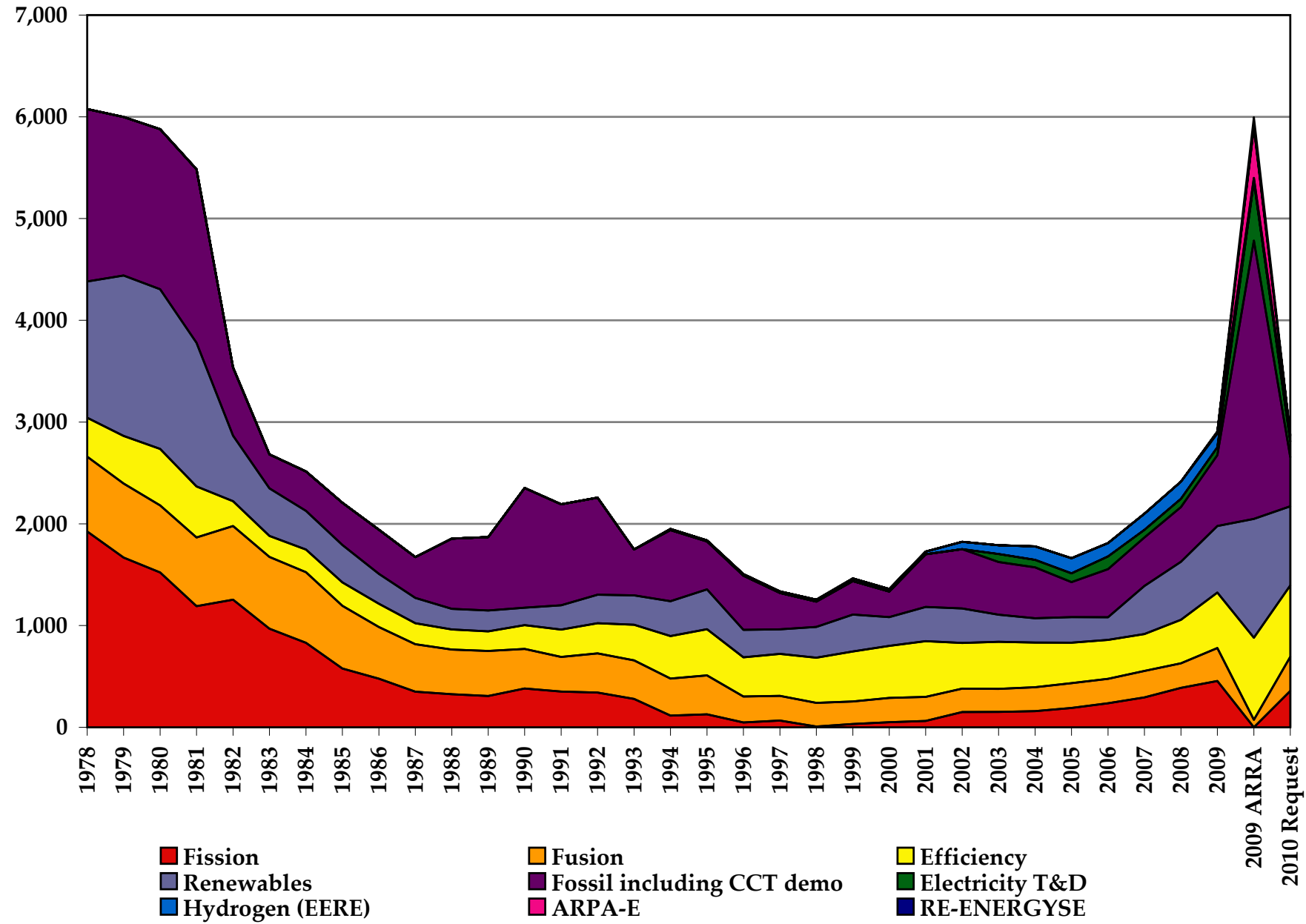

The Weatherization Assistance Program (WAP) doubled from \$223 million in FY 2008 to \$446 million in FY 2009, in spite of the fact that the FY 2009 request zeroed funds for the program. The FY 2010 request is similar to the FY 2008 enacted budget, but the Recovery Act represents over a 10 fold increase in program size over the FY 2009 appropriations, at a cost of $\$ 4.9$ billion, which will be a challenge to manage.

With over $\$ 7.5$ billion, the Advanced Technology Vehicles Manufacturing Loan program (ATVM) represents the largest single deployment appropriation administered through DOE. ATVM was established in the Energy Security Act of 2007 and its aim is to support a maximum of $\$ 25$ billion in loans for "automobile and automobile part manufacturers for the cost of re-equipping, expanding, or establishing manufacturing facilities in the United States to produce advanced technology vehicles or qualified components, and for associated engineering integration costs." 17 In March DOE announced that it would "consider and evaluate substantially complete applications

\footnotetext{
${ }_{17}$ The decision to appropriate funds to cover the cost of possible counterparty defaults by the ATVM program (and at such a high rate of the total loan value, i.e. $30 \%$ ) may be caused by the perceived high-risk of the projects and/or inability of counterparties to contribute upfront to cover this cost.
} 


\section{Table I: DOE deployment programs related to the energy efficiency portfolio in FY 2008, FY 2009, the ARRA 2009, and the FY 2010 budget request*}

(in millions 2000\$)

\begin{tabular}{|l|c|c|c|c|}
\hline Program & $\begin{array}{c}\text { FY } \\
2008\end{array}$ & $\begin{array}{c}\text { FY } \\
2009\end{array}$ & $\begin{array}{c}\text { ARRA } \\
2009\end{array}$ & $\begin{array}{c}\text { FY } \\
2010\end{array}$ \\
\hline $\begin{array}{l}\text { Conservation Weatherization Program } \\
\text { Excluding Training and Technical Assistance }\end{array}$ & 223 & 446 & 4,900 & 220 \\
\hline Federal Energy Management Program & 20 & 22 & 0 & 32 \\
\hline State Energy Program Grants & 44 & 50 & 3,100 & 75 \\
\hline Energy Efficiency and Conservation Block Grants & 0 & 0 & 3,200 & 0 \\
\hline $\begin{array}{l}\text { Advanced Technology Vehicles Manufacturing Loans } \\
\text { Renewable, adv. fossil, hydrogen fuel cells, }\end{array}$ & 0 & 7,510 & 10 & 20 \\
\hline $\begin{array}{l}\text { Innovative Technology Loan Guarantee Program } \\
\text { adv. nuclear, CCS, efficiency, pollution control, refineries }\end{array}$ & 5 & 0 & 0 & 0 \\
\hline $\begin{array}{l}\text { Section 1705 temporary loan guarantee program } \\
\text { Commercial technologies, incl. renewable electricity, } \\
\text { thermal energy, electric T\&D, innovative biofuels (to be } \\
\text { spent by 2011) }\end{array}$ & 0 & 0 & 5,990 & 0 \\
\hline Smart Grid Investment Program & 0 & 0 & 3,376 & 0 \\
\hline
\end{tabular}

* The funds on this table are appropriated amounts. In the case of loan guarantees, the amount of the loans that would be guaranteed would be far larger.

for loans under the program when they are submitted" and that it may make decisions on applications at any time, thereby expediting the processing of the loans (DOE 2009f) ${ }^{18}$.

Loan guarantees are another important element of DOE's support for technology deployment. The Energy Policy Act of 2005 (EPAct) authorized loan guarantees for innovative low-carbon energy technologies (DOE 2009g). ${ }^{19}$ In June 2008, DOE announced a second round of solicitations for $\$ 30.5$ billion in loan guarantees distributed as follows: up to $\$ 18.5$ billion for nuclear facilities, up to $\$ 2.0$ billion for facilities for the "front-end" of the nuclear cycle, and up to $\$ 10$ billion for EERE and advanced transmission and distribution projects (DOE 2008a and 2009g). The third round was announced in September 2008 and it included $\$ 8.0$ billion in loan guarantees for projects that employ advanced coal-based power generation, industrial gasification, and advanced coal gasification (DOE 2008b). ${ }^{20}$ Under the loan guarantee program, DOE requires that companies receiving the guaran-

\footnotetext{
${ }^{18}$ On June 23 2009, as this report was being finalized, the Obama Administration announced that it would award $\$ 8$ billion in conditional loan guarantees to Ford, Nissan, and Tesla under the AVTM program [http:// www.energy.gov/news2009/7486.htm].

${ }_{19}$ The program includes biomass, hydrogen, solar, wind and hydropower, advanced fossil energy coal, carbon sequestration practices and technologies, electricity delivery and energy reliability, alternative fuel vehicles, industry energy efficient projects, and pollution control equipment (DOE 2009g).

${ }^{20}$ The $\$ 8$ billion loan guarantee authority for "innovative clean coal technologies," which has not resulted in any appropriations so far, includes \$6 billion for CCS or other carbon emissions reducing technologies for retrofitted or new coal-based power generation plants, and $\$ 2$ billion for "advanced coal gasification projects which convert coal cleanly into electricity, hydrogen, and other valuable energy products" (DOE 2008b). The $\$ 2$ billion in loan guarantee authority could potentially be used to partially support the construction of coalto-liquids projects recommended by the NAS report (NAS 2009).
} 
tees pay the government a fee equal to the government's estimate of the cost of the risk the government is taking on (unless DOE receives an appropriation for the subsidy cost) ${ }^{21}$ if the government's estimates of its costs prove to be accurate, these programs should not result in net costs to taxpayers, but if DOE underestimated the risks and large projects went into default, taxpayers would be on the hook for billions of dollars to pay off the guaranteed loans.

Since EPAct offered no appropriations for the loan guarantees, DOE has been proposing to require firms to pay these subsidy costs up-front, "at or before the closing," (DOE 2006) which could substantially reduce the benefit of the federal loan guarantee, particularly for smaller firms less able to finance large up-front loan costs. In February 2009 Secretary Chu announced a series of reforms to make the loan guarantee program faster and more efficient, including offering the option to firms of paying the subsidy costs over the life of the loan, rather than at or before closing on the loan (DOE 2009h) (whether it will be implemented on a case-by-case basis, apply to all applicants with certain characteristics, or apply to all applicants is yet to be determined (Massouh et al. 2009)). Massouh et al. (2009) have argued that the current process focuses heavily "on the bankability of the applicants' projects and the creditworthiness of the applicants themselves," which fails to take into account the characteristics of some potential applicants, like start-up technology companies which may have no commercially proven revenue streams. The Recovery Act appropriated $\$ 6$ billion to allow DOE rather than borrowers to cover subsidy costs for some projects, with a focus on renewable energy projects, electric power transmission systems, and innovative biofuels projects. This initiative has been called the Temporary Loan Guarantee Program and is set to expire in September 2011 (CRS 2009). Congress is now considering additional legislation that would offer more flexible financing authorities and establish a new Clean Energy Deployment Authority (CEDA) within DOE.

In March 2009, Secretary Chu announced that DOE was offering its first loan guarantee of \$535 million to a solar company, Solyndra, to construct a commercial-scale manufacturing plant supported by the Recovery Act (DOE 2009i). A variety of other low-carbon energy projects are at varying stages of discussion with DOE over loan guarantees. The nuclear industry has been particularly active in seeking loan guarantees, and lobbied unsuccessfully to have tens of billions in additional loan guarantees for nuclear facilities included in ARRA. Ten nuclear projects applied for loan guarantees in the original program, and DOE is pursuing detailed discussions with four of them; DOE does not expect that the $\$ 18.5$ billion for guarantees for nuclear power plants in EPAct will extend beyond the first four projects (O'Grady 2009). ${ }^{22}$

Other major deployment programs funded by the Recovery Act include $\$ 3.1$ billion for state energy grants, $\$ 3.2$ billion for the energy efficiency and conservation block grants, and $\$ 3.0$ billion other advanced battery manufacturing, alternative fueled vehicles pilot, transportation electrification, and energy efficient appliance rebates. The combination of the deployment programs that have already been mentioned and the Federal Energy Management Program add up to \$287 million appropriated in FY 2008, \$8.0 billion in the enacted FY 2009 budget, \$14.2 billion in ARRA, and \$347 million for the FY 2010 request. Clearly, managerial, human resources and financial process issues will be more important than ever to transparently and effectively invest those huge resources. The

\footnotetext{
${ }^{21}$ Title XVII of the Energy Policy Act of 2005, which is the piece of legislation that authorized the program, specifies that "DOE must receive either an appropriation for the Subsidy Cost or payment of that cost by the borrower. The Subsidy Cost is the expected long-term liability to the Federal government in issuing the loan guarantee. No funds have been appropriated for the Subsidy Cost of loan guarantees. Therefore, DOE anticipates that the borrower (the sponsors) of a project approved to receive loan guarantee pursuant to the first solicitation will pay this cost" (DOE 2009g and 2006).

${ }^{22}$ Although not discussed on this document there may be activity in other technology areas of the loan guarantee program.
} 
deep cut in funding for these programs from budget enacted in FY 2009 to the request for FY 2010 is taking into account the funds appropriated in the Recovery Act.

\section{CONCLUSION}

The combination of the FY 2010 budget request for DOE and the portion of the ARRA funds likely to be available in 2010 would (if we assume that they would be split evenly between FY 2010, and FY 2011) result in a doubling in funding available for ERD\&D from \$3.6 billion in FY 2009 to $\$ 7.2$ billion in FY 2010. Without the stimulus funds, DOE ERD\&D investments in FY 2010 would decrease very slightly when compared to FY 2009. Excluding the $\$ 7.5$ billion for the Advanced Technology Vehicles Manufacturing Loans in FY 2009, the FY 2010 budget request for deployment represents a 33\% decrease from the FY 2009 levels from \$520 million to \$350 million. This decrease is largely due to the large amounts of funds appropriated in ARRA for DOE deployment programs, or $\$ 23.6$ billion, which are three times greater than those appropriated in the FY 2009 budget. These very substantial funding amounts, coupled with the broad range of institutional innovations the administration is putting in place and movement toward putting a price on carbon emissions, will help accelerate innovation for a broad range of energy technologies.

ARPA-E and the Energy Innovation Hubs are important initiatives that could contribute to two weak points of the government's energy innovation effort, namely funding high-risk projects in transformational technologies and in companies that have not traditionally worked with the government, and strengthening the integration of basic and applied research in priority areas.

Increasing the funding for different types of energy storage research, providing some support for exploring opportunities in coal-to-liquids with CCS and coal-and-biomass-to-liquids with CCS, and reducing funding for fission RD\&D are other actions that Congress could take in the shortterm. Energy storage may play a crucial role in the future of the power and transportation systems, which together consume two thirds of primary energy in the United States. A recent NAS report recommended carrying out detailed scenario assessments of the penetration of unconventional fuels from coal and coal and biomass with CCS. And the research plan provided for nuclear fission does not justify spending as many funds as were requested.

The proposed funding for FY 2010 and the resources from ARRA, however, do not guarantee that the United States will finally enjoy the predictable and consistent publicly-funded energy technology innovation effort that it needs. The Obama administration must put in place a comprehensive energy technology innovation strategy that will ensure that an expanded ERD3 effort is both sustainable and efficient. We recommend that a commission be created to develop such a strategy in the next 12 months. This commission would be charged with, inter alia, developing a strategy that optimizes the integration of the various stages of innovation (research, development, demonstration, early deployment), as well as integrates efforts across technology areas. 


\section{REFERENCES}

Anadon, Laura D., Matthew Bunn, Kelly Sims Gallagher, and Charles Jones. 2009. Tackling U.S. Energy Challenges and Opportunities: Preliminary policy recommendations for enhancing energy innovation in the U.S. Report, Energy Technology Innovation Policy Research Group, Belfer Center for Science and International Affairs, Harvard Kennedy School. February 18.

Anadon, Laura D., and John P. Holdren. 2009. Policy for Energy-Technology Innovation. In Acting in Time on Energy Policy, ed. Kelly Sims Gallagher, Washington DC: Brookings Institution Press.

APS. 2008. Energy Future. Think Efficiency. How America can look within to achieve energy security and reduce global warming. American Physical Society. September.

ARPA-E. 2009. Recovery Act - Financial Assistance Funding Opportunity Announcement. DEFOA-0000065. Advanced Research Projects Agency-Energy. April 27.

- - - 2005. Nuclear Power and Proliferation Resistance: Securing Benefits, Limiting Risk. Nuclear Energy Study Group, American Physical Society Panel on Public Affairs. May.

Bullis, Kevin. 2009. Q \& A: Steven Chu. Technology Review, May 14.

Bunn, Matthew. 2007. Risks of GNEP's Focus on Near-Term Reprocessing. Testimony to the Senate Committee on Energy and Natural Resources. November 14.

Chu, Steven. 2009. Statement of Steven Chu, Secretary, U.S. Department of Energy, before the Senate Committee on Appropriations Subcommittee on Energy and Water Development, and Related Agencies. FY 2010 Appropriations Hearing. May 19.

CRS. 2009. Energy Provisions in the American Recovery and Reinvestment Act of 2009 (P.L. 111-5), R40412. Congressional Research Service. Washington DC. May 12.

DOE .2009a. FY 2010 Congressional Budget Request. Offices of Energy Efficiency and Renewable Energy, Electricity Delivery and Energy Reliability, Energy Transformation Acceleration Fund, and Nuclear Energy. Volume 3, pp. 64. May.

- - - . 2009b. President Obama announces over $\$ 467$ million in Recovery Act funding for geothermal and solar energy projects. May 27. Available from http://www.energy.gov/news2009/7427. htm. [Accessed 06/04 2009].

- - - 2009c. Secretary Chu announces nearly $\$ 800$ million from Recovery Act to accelerate biofuels research and commercialization. New green jobs a benefit of effort to end dependence on foreign oil. May 5. Available from http://www.energy.gov/news2009/7375.htm. [Accessed 05/29 2009].

- - - 2009d. Secretary Chu, Governor Patrick announce \$25 million for Massachusetts Wind Technology Testing Center. May 12. Available from http://apps1.eere.energy.gov/news/news detail.cfm/news id=12504. [Accessed 05/29 2009].

- - - 2009e. Secretary Chu announces agreement on FutureGen Project in Mattoon, IL: Paves Way for First U.S. Commercial Scale Carbon Capture and Storage Project. June 12. Available from http://www.energy.gov/news2009/7454.htm [Accessed 06/27 2009].

- - - 2009f. Advanced Technology Vehicles Manufacturing Loan Program. Available from http:// www.atvmloan.energy.gov/. [Accessed 05/30 2009]. 
- - . 2009g. CFO Home. Loan Guarantee Program. Program Background. Available from http:// www.lgprogram.energy.gov/features.html. [Accessed 06/04 2009].

- - - 2009h. DOE Secretary Chu Announces Changes to Expedite Economic Recovery Funding: Restructuring will lead to new investments in energy projects within months. February 19. Available from http://www.energy.gov/news2009/6934.htm. [Accessed 06/11 2009].

- - - 2009i. Obama Administration Offers \$535 Million Loan Guarantee to Solyndra, Inc.: Investment Could Lead to Thousands of New Jobs. Office of Public Affairs. March 20.

- - - 2008a. DOE Announces Solicitations for \$30.5 billion in Loan Guarantees: Second Round of Solicitations includes renewable energy, nuclear, and 'front-end' nuclear power facility projects. Office of Public Affairs. June 30.

- - - 2008b. DOE Announces Solicitation for \$8.0 Billion in Loan Guarantees: Third Round of Solicitations Targets Innovative Clean Coal Technologies. Office of Public Affairs. September 22.

- - - 2006. Loan Guarantee Solicitation Announcement: Federal Loan Guarantees for Projects that Employ Innovation Technologies in Support of the Advanced Energy Initiative. Loan Guarantee Program Office. August 8.

EERE. 2009 Financial Opportunities - Solicitations. Recovery Act: Geothermal technologies program. DOE Office of Energy Efficiency and Renewable Energy. Available from http://www1.eere. energy.gov/geothermal/current opportunities.html. [Accessed 05/29 2009]

Energy Washington Week. 2009. DOE Aims To Spend 70 Percent Of Stimulus Funds By Labor Day 2010. Energy Washington Week 6 (21), May 27.

Gallagher, Kelly Sims, and Laura D. Anadon. 2009. DOE Budget Authority for Energy Research, Development, and Demonstration Database, Energy Technology Innovation Policy, John F. Kennedy School of Government, Harvard University. June 2. http://belfercenter.ksg.harvard.edu/ publication/19119/

Massouh, Jennifer F., George D. Cannon Jr., Suzanne M. Logan, and David L. Schwartz. 2009. Real Promise or False Hope: DOE’s Title XVII Loan Guarantee. Electricity Journal 22 (4):53.

MIT. 2003. The Future of Nuclear Power. An Interdisciplinary MIT Study. Massachusetts Institute of Technology.

NAS. 2009. Liquid Transportation Fuels from Coal and Biomass: Technological Status, Costs, and Environmental Impacts. Prepublication Copy. The National Academies. Washington DC: The National Academies Press.

NCEP. 2004. Ending the Energy Stalemate. A Bipartisan Strategy to Meet America's Energy Challenges. The National Commission on Energy Policy.

NRC. 2007. Review of DOE's nuclear energy research and development program. Committee on Review of DOE's Nuclear Energy Research and Development Program. National Research Council. Committee on Review of DOE's Nuclear Energy Research and Development Program. Washington DC: National Academies Press.

Ogden, Peter, John Podesta, and John Deutch. 2008. A New Strategy to Spur Energy Innovation. Issues in Science and Technology. Winter.

O'Grady, Eileen. 2009. DOE Working With Four Nuclear Developers. Reuters, June 1. 


\section{Energy Technology Innovation Policy}

The overarching objective of the Energy Technology Innovation Policy (ETIP) research group is to determine and then seek to promote adoption of effective strategies for developing and deploying cleaner and more efficient energy technologies, primarily in three of the biggest energyconsuming nations in the world: the United States, China, and India. These three countries have enormous influence on local, regional, and global environmental conditions through their energy production and consumption. ETIP researchers seek to identify and promote strategies that these countries can pursue, separately and collaboratively, for accelerating the development and deployment of advanced energy options that can reduce conventional air pollution, minimize future greenhouse-gas emissions, reduce dependence on oil, facilitate poverty alleviation, and promote economic development. ETIP's focus on three crucial countries rather than only one not only multiplies directly our leverage on the world scale and facilitates the pursuit of cooperative efforts, but also allows for the development of new insights from comparisons and contrasts among conditions and strategies in the three cases.

www.energytechnologypolicy.org

\section{Energy Research, Development, Demonstration \& Deployment (ERD3) Project}

The ERD3 Project is a three-year effort within ETIP funded by the Doris Duke Charitable Foundation aimed at producing a set of comprehensive recommendations for the Obama administration to accelerate energy technology innovation (ETI). ERD3 Project members are working in three main areas: (a) identifying the opportunities for government-funded energy research development and demonstration (ERD\&D), and developing a portfolio of U.S. government investments in ERD\&D as components of a coordinated ETI strategy; (b) understanding the private sector's current role in carrying out and funding ERD\&D in the United States and drawing conclusions about effective structures of public-private undertakings and other incentives to promote private sector innovation; and (c) analyzing the global picture of ETI to make recommendations on a strategy and priorities for international cooperation on ETI for the United States.

\section{http://belfercenter.ksg.harvard.edu/project/10/energy_technology_innovation_policy. html?page_id=213}

Please visit us at www.energytechnologypolicy.org or contact us by e-mail at etip@ksg.harvard.edu.

Energy Technology Innovation Policy

Belfer Center for Science and International Affairs

Harvard Kennedy School of Government

Harvard University

79 John F. Kennedy Street, Mailbox 53

Cambridge, MA 02138 